\title{
Constructive thinking and burnout among secondary school teachers
}

Citation for published version (APA):

Evers, W., Brouwers, A., \& Tomic, W. (2005). Constructive thinking and burnout among secondary school teachers. Social Psychology of Education, 2005(8), 425-439. https://doi.org/10.1007/s11218-005-0663-8

DOI:

10.1007/s11218-005-0663-8

Document status and date:

Published: 01/11/2005

Document Version:

Peer reviewed version

Please check the document version of this publication:

- A submitted manuscript is the version of the article upon submission and before peer-review. There can be important differences between the submitted version and the official published version of record. People interested in the research are advised to contact the author for the final version of the publication, or visit the DOI to the publisher's website.

- The final author version and the galley proof are versions of the publication after peer review.

- The final published version features the final layout of the paper including the volume, issue and page numbers.

Link to publication

\section{General rights}

Copyright and moral rights for the publications made accessible in the public portal are retained by the authors and/or other copyright owners and it is a condition of accessing publications that users recognise and abide by the legal requirements associated with these rights.

- Users may download and print one copy of any publication from the public portal for the purpose of private study or research.

- You may not further distribute the material or use it for any profit-making activity or commercial gain

- You may freely distribute the URL identifying the publication in the public portal.

If the publication is distributed under the terms of Article 25fa of the Dutch Copyright Act, indicated by the "Taverne" license above, please follow below link for the End User Agreement:

https://www.ou.nl/taverne-agreement

Take down policy

If you believe that this document breaches copyright please contact us at:

pure-support@ou.nl

providing details and we will investigate your claim.

Downloaded from https://research.ou.nl/ on date: 26 Apr. 2023 


\title{
Constructive thinking and burnout among secondary school teachers
}

\author{
WILL EVERS, WELKO TOMIC* and ANDRÉ BROUWERS \\ Faculty of Social Sciences, The Open University, P.O. Box 2960, \\ NL-6401 DL Heerlen, The Netherlands
}

(Received 7 December 2004; Accepted in final form 5 July 2005)

\begin{abstract}
The present study investigated the relationship between Epstein's (1998, Constructive thinking: The key to emotional intelligence. London: Praeger publisher.) components of constructive thinking and burnout as experienced by a sample of Dutch secondary school teachers. A postal questionnaire was sent to teachers from randomly selected secondary schools. The response rate was $54.1 \%(N=433)$. Four components of constructive thinking significantly contributed to the explained variance in emotional exhaustion $(17 \%)$, depersonalization $(21 \%)$, and personal accomplishment $(20 \%)$. The results of the study suggest that secondary school teachers' maladaptive thinking processes prevent them from rational thinking during their work, which significantly contributes to the onset of burnout. Burnout intervention programs for teachers are likely to be more effective when the participator's maladaptive thinking system is taken into consideration. This stems from the idea that personality factors are a probably easier point of departure to tackle burnout symptoms than organizational factors.
\end{abstract}

Key words: burnout; constructive thinking; secondary school teachers

\section{Introduction}

\subsection{BURNOUT}

Burnout is a syndrome that has been mainly observed in individuals whose professional demands include both a high sense of ideals and a high degree of interaction with other people, for instance teachers and medical personnel. Burnout is divided in three dimensions, emotional exhaustion, depersonalization, and reduced personal accomplishment. Characteristic for emotional exhaustion is for instance the feeling of being emotionally drained by work, or used up at the end of almost every workday. Depersonalization is characterized by feelings of callousness towards other people. Finally, burned out individuals suffer from a reduced sense of personal accomplishment, or the feeling that one is dealing less effectively with problems as well as with

${ }^{\star}$ Author for correspondence: Tel.:+345-5762539; Fax: +3145-5762939; e-mail: Welko.Tomic@ou.nl. 
students and peers (Burke, Greenglass, \& Schwarzer, 1996; Freudenberger, 1974; Glass \& McKnight, 1996; Greenglass, 2001; Maslach \& Jackson, 1981; Maslach, 1982; Maslach \& Jackson, 1986).

According to Huberman and Vandenberghe (1999) research shows that a considerable number of teachers both in Europe and in North America are troubled by increased workloads, impracticable innovations, conflicting interests, little social support, or disruptive and undisciplined students. Current teachers working in these demanding surroundings have difficult and exacting jobs to perform. In the Netherlands, the Central Statistical Office published data revealing that burnout in the world of education is more frequent than in any other branch of industry or human service organization, like construction, transport, health-care, or hotel and catering industry (CBS, 1999). This finding is in line with research showing that an important number of teachers say that they feel they might leave the job and that they have had enough of their work (Berkhout, Zijl, \& van Praag, 1998; Friedman \& Farber, 1992). So it is quite logical that burned out teachers are not able to properly perform their job any longer.

Both external and internal circumstances are found to contribute to the beginning and development of burnout among teachers. External circumstances such as organizational characteristics or composition of students per class fall outside the teacher's power of decision, and are very much the same for many teachers. Still, the fact remains that there are significant differences in burnout scores among teachers of one and the same organization who seem to work under almost the same work conditions, This is a puzzling finding and has not been examined yet as far as we know.

Although many studies have been conducted on teacher burnout, little is known about the relationship between Epstein's concept of constructive thinking and teacher burnout. That is why the present paper departs from a psychological orientation and not from organizational or other work-related contributors to the origin of burnout. It focuses on one of the teachers' personal characteristics, his or her pattern of thought, in order to find out to which degree it may influence the onset of burnout.

\subsection{THE RATIONAL, ASSOCIANISTIC AND EXPERIENTIAL SYSTEM}

People who find themselves in the same position, do not always experience the same amount of stress. Some authors, for example Byrne (1999) and Rudow (1999), assume that the degree of experienced stress is partly defined by personality variables. An example of such a personality variable is someone's pattern of thought, which plays an important, but not sole role in manifestations of human behavior.

According to Epstein and Meier (1989) human perception and behavior is controlled by three different systems, the rational, the associanistic and the experiential system. 
The rational system enables the individual to adapt oneself to the outside world with the help of language and logic. The associanistic system is for instance manifest in dreams and operates unconsciously. Finally, the experiential system operates in the same way as it does in animals, automatically and instinctively. Learning from experiences, linking up connections between one's own behavior and the ensuing results, enables the individual to get a picture of his surroundings and influence on it (Goleman, 1996).

In everyday life people usually avail themselves of the experiential system (Epstein, 1998). However, sometimes the experiential system can provide us with rather inadequate responses in specific situations. For instance, in times of strong emotional excitement individuals are apt to show uncontrolled and stress-arousing behavioral reactions. However, Epstein believes that human beings are able to reflect on routine behavior patterns: constructive thinking may help change our pattern of thought.

\subsection{STRESS AND CONSTRUCTIVE THINKING}

Epstein defined constructive thinking as"... the degree to which a person's automatical thinking - the thinking that occurs without deliberate intention - facilitates solving problems in everyday life at a minimum cost in stress" (Epstein, 1998, p. 26). The definition shows that someone's stress level can be influenced when not only coping strategies, as in most stress-reducing programs occurs, but also underlying thinking patterns are taken into consideration. There are three reasons why constructive thinking helps reduce the experience of stress. First of all, constructive thinking reduces the possibility of a self-created stressful environment and promotes organized and efficient behavior. Second, constructive thinking helps the individual interpret a potential stressor as a challenge instead of a threat. For instance, disappointments are looked upon as temporary set-backs that can eventually be overcome. Finally, real stressors are approached more effectively by individuals who apply constructive thinking. Uncontrolled emotional reactions in case of a stressful event do not contribute to the solution of the underlying problem, whereas constructive thinking does.

Constructive thinking consists of several components that will be discussed in brief as far as necessary in understanding the measurement instrument of our examination. The first component is called negative self-oriented cognitive style. It refers to negative self-evaluations, doubt, and personal failure. According to Epstein (1982, 1992) negative automatic thoughts are an important source of negative affect, helplessness and depression. The component positive self-oriented cognitive style refers to an optimistic attitude of life and positive self-evaluations. Positive oriented individuals do not indulge in useless doom-mongering nor in getting stuck in unpleasant past experiences. The positive other-oriented cognitive 
style refers to a high degree of confidence in others, for instance peers in the workplace. Having faith in colleagues, clients and students helps bring about a positive work climate for all individuals involved. Magical thinking refers to superstitious beliefs, such as the individual's conviction that good events will always be followed by something unpleasant. Individuals who apply magical thinking are often characterized by feelings of helplessness. This way of thinking offers no point of departure with reality. The last component refers to dichotomic thinking or the so-called "black and white" thinking. Individuals who employ dichotomic thinking believe there are only two alternatives, one of which is right and the other wrong. According to Epstein and Meier (1989) it is a kind of rigid and maladjusted way of thinking leading to intolerant and denouncing behavior towards others. Dichotomic thinking is found to be correlated with feelings of anxiety and rigidity (Epstein, 1992).

\subsection{HYPOTHESES}

Our study examines the relationship of the dimensions of burnout with the various components of constructive thinking. First, we assume that teachers with high scores on negative self-oriented thinking will suffer from high levels of burnout. Second, we assume that teachers with high scores on positive self-oriented thinking will display low levels of burnout. Third, we assume that teachers with high scores on positive other-oriented style, will display low levels of burnout. Four, we assume that teachers with high scores on magical and dichotomic thinking will display high levels of burnout.

\section{Method}

\subsection{PARTICIPANTS}

We conducted our examination among secondary school teachers in the Netherlands. In all, 433 teachers completely filled out our questionnaires, 206 female $(47.6 \%)$ and 227 males (52.4\%). The teachers' mean age was 45.56 years $(\mathrm{SD}=9.81)$, ranging from 21 to 61 . The mean experience in teaching was 16.34 years $(\mathrm{SD}=11.12)$, ranging from 0 to 45 . The mean number of weekly lessons was $19.45(\mathrm{SD}=6.19)$.

\subsection{INSTRUMENTS}

Constructive thinking was measured with the Test for Cognitive Styles (TCS, Den Boer, Rombouts, Appelo, \& Wolter, 1999) which consists of 37 items. The TCS is based on the Constructive Thinking Inventory (Epstein \& Meier, 1989). The American CTI was not only translated into the 
Dutch language, but also adapted after a pilot study with explorative factor analysis. The resulting concept-TCS-was validated among 734 respondents, and the items appeared to load on five factors, namely negative self-oriented cognitive style (example: "I am very sensitive to encounter rejections"; 15 items), positive self-oriented cognitive style (example: "When I have to perform a difficult task, I think about positive things"; 7 items), positive other-oriented cognitive style (example: "Most people can be trusted"; 7 items), magical thinking (example: "I have at least one good-luck charm"; 5 items), and dichotomous thinking (example: "Once a thief, always a thief"; 3 items; see for more examples De Boer, et al., 1999). The items were scored on a five-point scale, ranging from seldom to often. The scores of each sub-scale were added up. Indicative of constructive thinking are high scores on the positive self-oriented cognitive scale, and the positive other-oriented cognitive scale and low scores on the negative self-oriented cognitive scale, magical thinking and dichotomous thinking.

Burnout was measured with the Dutch version of the Maslach Burnout Inventory for teachers (MBINI-Le) (Schaufeli \& Van Horn, 1995). The questionnaire is divided into three subscales, and consists of 20 items that were scored on a 7-point scale, ranging from "never" to "always". The first subscale is emotional exhaustion ( 8 items; e.g. "I feel used up at the end of the working day"); the second subscale is depersonalization (5 items; e.g. "I don't really care what happens to some students"); and the last one is personal accomplishment (7 items; e.g, "I have accomplished many worthwhile things in this job").

The three factor structure of the Dutch version of the MBI was confirmed by Schaufeli, Daamen and Van Mierlo (1994).

\subsection{PROCEDURE}

We at random approached secondary schools in the Netherlands over the telephone. After having explained the aim and kind of the investigation, we asked the various principals for cooperation. Eventually, ten schools were prepared to participate in our investigation. The questionnaires were accompanied by explanatory letters for the teachers. Two weeks later we visited the schools to collect the questionnaires. In general, investigations of this kind have a respondence of about 30\%; in our case the responserate was $54.1 \%$ (800 questionnaires distributed, 433 fully filled out questionnaires received).

\section{Results}

In order to find out whether the TCS reflects 5 cognitive styles, Table I shows the results of a principal component analysis with varimax rotation. The 
Table I. Results of principal component analysis of the TCS with varimax rotation

\begin{tabular}{|c|c|c|c|c|c|}
\hline \multirow{2}{*}{$\begin{array}{l}\text { Item } \\
\text { No. }\end{array}$} & \multirow[t]{2}{*}{ Item } & \multicolumn{4}{|c|}{ Factors } \\
\hline & & 1 & 2 & 3 & 45 \\
\hline & Negative Self-oriented Style & & & & \\
\hline 5. & I am very sensitive to rejections & 0.76 & & & \\
\hline 7. & The slightest rejection can upset me & 0.74 & & & \\
\hline 4. & $\begin{array}{l}\text { I much more think about my mistakes than } \\
\text { about things that go well }\end{array}$ & 0.72 & & & \\
\hline 2. & I think it is terrible to fail & 0.69 & & & \\
\hline 13. & $\begin{array}{l}\text { When I am rejected by someone who is dear } \\
\text { to me I feel a failure }\end{array}$ & 0.68 & & & \\
\hline 14. & I don't think much of everything I do & 0.68 & & & \\
\hline 8. & I get upset when I can't manage & 0.67 & & & \\
\hline 3. & $\begin{array}{l}\text { When someone I love rejects me I feel } \\
\text { worthless }\end{array}$ & 0.65 & & & \\
\hline 1. & $\begin{array}{l}\text { I always feel I don't come up to the } \\
\text { mark even though I try to do my utmost }\end{array}$ & 0.63 & & & \\
\hline 9. & I often worry about people's opinion on me & 0.63 & & & \\
\hline 12. & I am very sensitive to mockery & 0.60 & & & \\
\hline 6. & $\begin{array}{l}\text { When I have to do a lot of work in time, I } \\
\text { feel it is too much for me }\end{array}$ & 0.56 & & & \\
\hline 10. & $\begin{array}{l}\text { My work must absolutely be perfect, } \\
\text { otherwise I feel a failure }\end{array}$ & 0.53 & & & \\
\hline 15. & $\begin{array}{l}\text { When I find myself in a new situation I } \\
\text { mostly think about a bad result }\end{array}$ & 0.46 & & & \\
\hline & Positive other-oriented style & & & & \\
\hline 25. & Most people can be trusted & & 0.80 & & \\
\hline 28. & You can trust someone rather quickly & & 0.77 & & \\
\hline 26. & There are sufficient thoughtful people & & 0.76 & & \\
\hline 27. & Someone who is kind to me wishes me well & & 0.71 & & \\
\hline 24. & $\begin{array}{l}\text { When you are kind to someone, he/she will } \\
\text { also be kind to you }\end{array}$ & & 0.63 & & \\
\hline 29. & $\begin{array}{l}\text { People are tolerant when you make a } \\
\text { mistake }\end{array}$ & & 0.55 & & \\
\hline 23. & $\begin{array}{l}\text { People are quick at reacting positively } \\
\text { Positive other-oriented style }\end{array}$ & & 0.54 & & \\
\hline 19. & $\begin{array}{l}\text { I look upon a challenge as a valuable } \\
\text { experience }\end{array}$ & & & 0.70 & \\
\hline
\end{tabular}


Table I. Continued

\begin{tabular}{|c|c|c|c|c|c|}
\hline \multirow{2}{*}{$\begin{array}{l}\text { Item } \\
\text { No. }\end{array}$} & \multirow[t]{2}{*}{ Item } & \multicolumn{4}{|c|}{ Factors } \\
\hline & & 12 & 3 & 4 & 5 \\
\hline 18. & $\begin{array}{l}\text { When I have to do something difficult, I think of } \\
\text { something positive }\end{array}$ & & 0.68 & & \\
\hline 16. & $\begin{array}{l}\text { look upon a challenge as a possibility to show how } \\
\text { capable I am }\end{array}$ & & 0.66 & & \\
\hline 20. & $\begin{array}{l}\text { When I have to do something that is unpleasant, } \\
\text { I try to make the best of it by positive thinking }\end{array}$ & & 0.62 & & \\
\hline 22. & $\begin{array}{l}\text { When confronted with unpleasant things I try } \\
\text { to think about a strategy how to enter on them }\end{array}$ & & 0.61 & & \\
\hline 21. & $\begin{array}{l}\text { When I am successful at something I will } \\
\text { be successful at it again in future }\end{array}$ & & 0.57 & & \\
\hline 17. & I can very well trust my first impressions & & 0.55 & & \\
\hline & Magical thinking & & & & \\
\hline 33. & $\begin{array}{l}\text { When I think of some people. I know it is because } \\
\text { they think of me. }\end{array}$ & & & 0.80 & \\
\hline 32. & $\begin{array}{l}\text { I believe that the moon and the stars } \\
\text { can influence people's thoughts }\end{array}$ & & & 0.74 & \\
\hline 30. & $\begin{array}{l}\text { I believe there are people who can get } \\
\text { their thoughts over into the minds of other people }\end{array}$ & & & 0.71 & \\
\hline 31. & $\begin{array}{l}\text { When I have nasty thoughts about someone, } \\
\text { I believe they can affect the well-being of that person }\end{array}$ & & & 0.69 & \\
\hline 34. & I have at least one good-luck charm & & & 0.43 & \\
\hline & Dichotomous thinking & & & & \\
\hline 36. & Once a thief, always a thief & & & & 0.76 \\
\hline 35. & $\begin{array}{l}\text { There are two possibilities: a correct answer or a } \\
\text { wrong answer }\end{array}$ & & & & 0.64 \\
\hline 37. & Everyone who is not too lazy, can find a job & & & & 0.60 \\
\hline
\end{tabular}

Note. Loadings $>0.43$.

factor analysis shows that items 1 up to and including item 15 load on factor 1(negative self-oriented cognitive style); items 16 up to and including item 22 load on factor 3 (positive self-oriented cognitive style); items 23 up to and including item 29 load on factor 2 (positive other-oriented cognitive style); items 30 up to and including item 34 load on factor 4 (magical thinking); and items 35 up to and including item 37 load on factor 5 (dichotomous 
thinking). Item 11("I shun challenges because failure is unbearable for me") was removed from analysis because it loaded on more than one factor. Only items with a value of 0.43 or higher were incorporated in Table I.

Table II shows the means, the standard deviations and Cronbach's alpha of the variables and intercorrelations between the variables. The reliability of most variables is 0.70 or higher, which is sufficient for group research in the present study (Nunnally \& Bernstein, 1994). Exceptions are the low reliabilities for depersonalization (0.66) and dichotomous thinking (0.52).

Table II shows that emotional exhaustion positively correlates with negative self-oriented cognitive style $(r=0.39, p<0.01)$. On the other hand, emotional exhaustion negatively correlates with positive self-oriented cognitive style $(r=-0.21, p<0.01)$ and positive other-oriented cognitive style $(r=-0.25, p<0.01)$.

Depersonalization positively correlates with negative self-oriented cognitive style $(r=0.39, p<0.01)$, and negatively with positive self-oriented and positive other-oriented cognitive style $(r=-0.22, p<0.01$, and $r=-0.27, p<0.01$, respectively). It also appears that depersonalization positively correlates with dichotomous thinking $(r=0.14, p<0.05)$.

With regard to personal accomplishment, the results show that this variable negatively correlates with negative self-oriented cognitive style, $(r=-0.26, p<$ 0.01 ), and positively with positive self-oriented and positive other-oriented cognitive style ( $r=0.32, p<0.01$, and $r=0.37, p<0.01$, respectively).

Finally, Table II shows that high scores on negative self-oriented cognitive style correlate with lower scores on positive self-oriented cognitive style $(r=-0.24, p<0.01)$ and positive other-oriented cognitive style $(r=$ $-0.16, p<0.01)$. Positive self oriented cognitive style positively correlates with positive other-oriented cognitive style $(r=0.40, p<0.01)$, and high scores on magical thinking positively correlate with positive self-oriented and positive other-oriented cognitive style $(r=0.28, p<0.01$, and $r=$ $0.12, p<0.05$, respectively).

A hierarchical regression analysis was carried out in order to examine to what extent the predicting variables negative self-oriented cognitive style, positive self-oriented cognitive style, positive other-oriented cognitive style, magic thinking, and dichotomous thinking would explain the teachers' burnout level.

Table III shows that several negative components of constructive thinking added in step two significantly contribute to one or more dimensions of the burnout syndrome. The variable negative self-oriented cognitive style is a significant predictor of emotional exhaustion $(\beta=0.34, p<$ $0.001)$, depersonalization $(\beta=0.34, p<0.001)$, and personal accomplishment $(\beta=-0.15, p<0.05)$. It means that hypothesis 1 is accepted. The variable positive self-oriented cognitive style is a significant predictor of personal accomplishment $(\beta=0.17, p<0.05)$, which means that hypothesis 2 is only accepted for one dimension of burnout. Positive other-oriented cognitive 


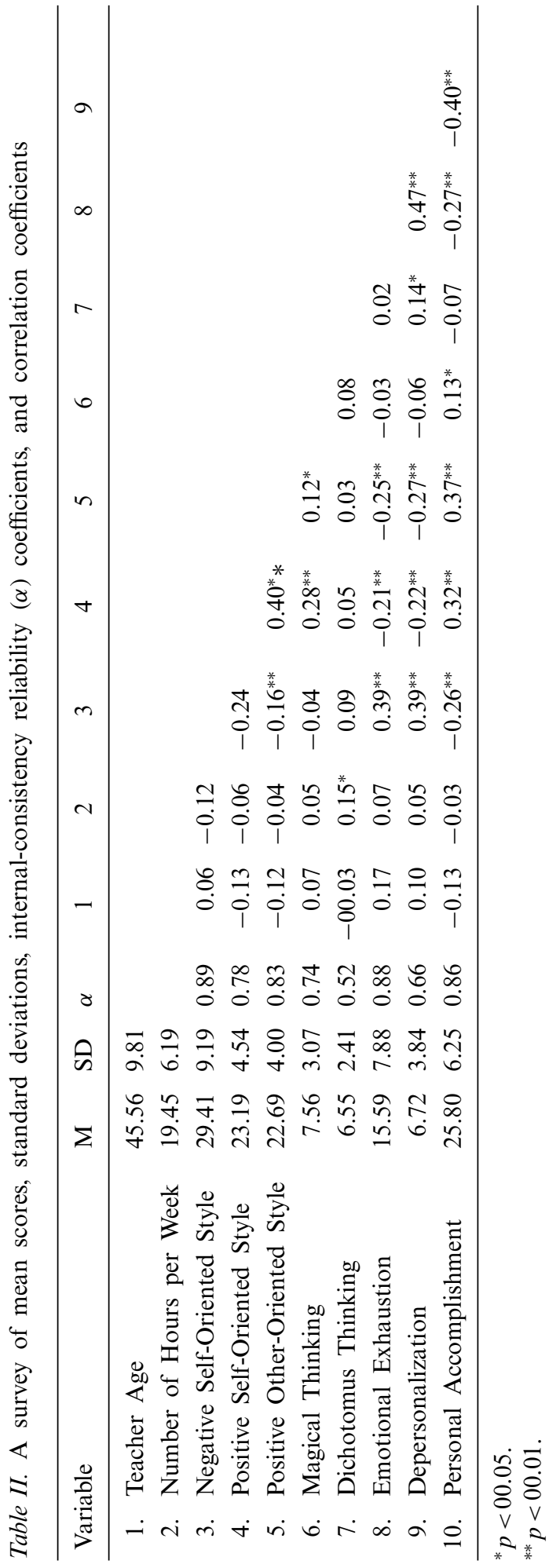


Table III. Results of the regression analyses for the predicting variables on emotional exhaustion, depersonalization, and personal accomplishment

\begin{tabular}{|c|c|c|c|c|c|c|}
\hline \multirow[t]{2}{*}{ Predictor variables } & \multicolumn{2}{|c|}{$\begin{array}{l}\text { Emotional } \\
\text { exhaustion }\end{array}$} & \multicolumn{2}{|l|}{$\begin{array}{l}\text { Deperson } \\
\text { alization }\end{array}$} & \multicolumn{2}{|c|}{$\begin{array}{l}\text { Personal accom- } \\
\text { plishment }\end{array}$} \\
\hline & $\beta$ & $\Delta R^{2}$ & $\beta$ & $\Delta R^{2}$ & $\beta$ & $\Delta R^{2}$ \\
\hline Step 1 & & 0.03 & & 0.01 & & 0.02 \\
\hline Gender & -0.04 & & -0.04 & & 0.02 & \\
\hline Age & -0.11 & & 0.05 & & -0.07 & \\
\hline Number of lessons & 0.09 & & 0.04 & & 0.00 & \\
\hline Step 2 & & $0.17^{* * *}$ & & $0.21^{* * *}$ & & $0.20^{* * *}$ \\
\hline Negative self-oriented style & $0.34^{* * *}$ & & $0.34^{* * *}$ & & $-0.15^{*}$ & \\
\hline Positive self-oriented style & -0.08 & & -0.08 & & $0.17^{*}$ & \\
\hline Positive other-oriented style & $-0.15^{*}$ & & $-0.18^{*}$ & & $0.28^{* * *}$ & \\
\hline Magic thinking & 0.03 & & 0.01 & & 0.03 & \\
\hline Dichotomous thinking & 0.02 & & $0.13^{*}$ & & -0.10 & \\
\hline Overall $F$-value & $60.54^{* * *}$ & & $70.30^{* * *}$ & & $60.94^{* * *}$ & \\
\hline
\end{tabular}

$\beta$ is the standardized regression coefficient of the full regression equation with all predicting variables. The increase $\mathrm{R}^{2}$ for the variables in one step is based on the $F$-test for the step concerned.

$* p<0.05$.

${ }^{* *} p<0.01$

*** $p<0.001$.

style is significantly related to emotional exhaustion $(\beta=-0.15, p<0.05)$, depersonalization $(\beta=-0.18, p<0.05)$, and personal accomplishment $(\beta=$ $0.28, p<0.001)$. It means that hypothesis 3 is accepted. Magic thinking is not a significant predictor of any of the three dimensions of burnout, whereas dichotomous thinking is a significant predictor of only depersonalization $(\beta=0.13, p<0.05)$, which means that hypothesis 4 is accepted for only one dimension of burnout, and that for the variable dichotomous thinking. In other words, the results show that when the effects of gender, age and lesson periods are statistically controlled for in step 1, the four predicting variables added in step 2 (negative self-oriented cognitive style, positive self-oriented cognitive style, positive other-oriented cognitive style, magic thinking, and dichotomous thinking) explain over $17 \%$ of variance in emotional exhaustion, $21 \%$ of variance in depersonalization, and $20 \%$ of variance in personal accomplishment. It means that these variables significantly contribute to the occurrence of the three dimensions of burnout. Moreover, the ANOVA table shows that the models as a whole are significant for emotional exhaustion $[F(8,200)=6.54, p<0.001]$, 
depersonalization $[F(8,200)=7.30, p<.001]$, and personal accomplishment $[F(8,200)=6.94, p<0.001]$.

\section{Discussion}

The aim of the present study was to examine whether components of constructive thinking would be related to one or more dimensions of the burnout construct. With regard to hypothesis 1 the results show that the component negative self-oriented cognitive style is significantly related to all three dimensions of burnout. Part of the explanation can be found in studies relating student behavior and the onset of symptoms of burnout among teachers (Brouwers \& Tomic, 1999; Byrne, 1991, 1999). As teaching is an inter-active and inter-personal process, teachers with a negative self-oriented cognitive style will probably interpret classroom problems and difficult student behavior as unsolvable problems they cannot cope with and which will therefore reinforce their negative self-image. Moreover, according to the teachers' professional code they are ethically focused on helping students, often neglecting their own needs (Nias, 1999). Nias posits that many teachers would sooner provide and care for their students than for themselves. However, teachers with high scores on negative self-oriented cognitive style feel unable to do so and blame themselves for their lack of accomplishment and skill. Resulting feelings of guilt and blame, and lack of self-efficacy will contribute to the onset of burnout (Brouwers \& Tomic, 2000; Cherniss, 1993; Evers, 2002; Schmitz, 2001).

Hypothesis 2 was partly confirmed. Positive self-orientation is only significantly related to personal accomplishment. This finding supports the results of studies that are proof of the relationships between the salutary effects of successes in one's personal professional life (Brouwers \& Tomic, 1999; Evers, 2002; Friedman \& Farber, 1992). Successes lead to self-confidence, increased levels of self-efficacy, and an optimistic view of one's capabilities. However, the expected correlations with the two other dimensions of burnout have not occurred.

Hypothesis 3 was confirmed. Teachers with high scores on positive other-oriented cognitive style will probably have good relationships with students and fellow-teachers. Consequently, they will experience only few or no inter-personal conflicts. Rudow (1999), for instance, found that skills such as sharing problems with others, avoiding confrontations, and feelings of empathy were important factors in the prevention of the onset of burnout.

Finally, hypothesis 4 was only confirmed for the correlation between dichotomous thinking and depersonalization. It is quite well possible that both dichotomous thinking and magical thinking are ways of thinking that are not much applied by teachers. First of all, teachers are professionals who have received training and education at a high level, and will therefore 
be accustomed to think logically and consider alternatives. Second, magical and dichotomous thinking is of no practical use in the upbringing of pupils, for each instructional and educational situation asks for multifarious thinking and acting. A more prosaic reason might be found in the nature of this examination: self-report questionnaires are susceptible to answers tinged with social desirability, thus concealing the teachers' actual use of dichotomous and magical thinking.

Constructive thinking is a concept used in for instance Rational Emotive Therapy (Ellis, 1996). RET can help people adopt different outlooks concerning initially experienced stress-inducing events and circumstances, so as to reduce or prevent mental illnesses. The results of the present study support the basic assumption of RET that the way of thinking applied by individuals will have an influence on his or her well being: thinking styles are of great influence on the individual's approach to people, problems, events and circumstances, in short to his or her surrounding world.

With respect to teachers, the results of the present study suggest that intervention programs promoting constructive thinking may be successful in the treatment of burned-out teachers. This finding also seems to be part of the explanation why some teachers working at the same school under almost the same circumstances suffer from symptoms of burnout and others do not. Someone's existential fulfillment is inextricably bound up with his or her way of thinking, which becomes manifest through the results of our previous examination of the relationship between existential fulfillment and burnout among teachers (Tomic, Evers, \& Brouwers, 2004). This paper suggests focusing on burnout in the framework of the "existential vacuum", which places the study of the burnout phenomenon in a broader perspective of the individual's total personality. However, as the results of the former and the present study are obtained from cross-sectional examinations, we recommend further research on the subject of teacher burnout in the framework of thinking styles and existential fulfillment.

Finally, teachers are confronted with many classroom situations that require quick and competent reactions. These reactions are more often than not controlled by the emotionally driven experiential system of thinking, which is very ineffective for both teacher and student. Resulting feelings of anger, disappointment, incompetence and inefficiency will call forth burnout symptoms of emotional exhaustion, depersonalization and lack of personal accomplishment. Although we do not deny the significance of organizational factors associated with the experience of burnout (Evers, Brouwers, \& Tomic, 2002), they were not the aim of the current study. As organizational contributors to the origin of burnout are very often intangible factors, intervention programs should focus on personal factors such as the individual's maladaptive way of thinking in taxing and stressful situations. This idea is in accordance with Cooley and Yovanoff 
(1996) who claim that intervention programs had better start from alterable factors within the burned-out teacher. It would be even a better idea to include courses on thinking processes in training programs for teachers, for self-knowledge on the various components of thinking may have a preventive and beneficial effect on the teacher's well-being during his or her career.

\section{References}

Berkhout, P.H.G., Zijl, M., \& van Praag, B.M.S. (1998). De leraar op de drempel van het millennium. Onderzoek naar de arbeidssatisfactie van leraren in het voortgezet onderwijs [The teacher on the threshold of the millennium. Research into job satisfaction among secondary school teachers]. Amsterdam: Stichting voor economisch onderzoek der Universiteit van Amsterdam.

Brouwers, A. (2000). Teacher burnout and self-efficacy: An interpersonal approach. Heerlen: The Open University.

Brouwers, A. \& Tomic, W. (1999). Teacher burnout, perceived self-efficacy in classroom management, and student disruptive behavior in secondary education. Curriculum and Teaching, 14(2), 7-26.

Brouwers, A. \& Tomic, W. (2000). A longitudinal study of teacher burnout and perceived self-efficacy in classroom management. Teaching and Teacher Education, 16(2), 239-253.

Burke, R.J., Greenglass, E.R., \& Schwarzer, R. (1996). Predicting teacher burnout over time: Effects of work stress, social support, and self-doubts on burnout and its consequences. Anxiety, Stress, and Coping, 9(3), 261-275.

Byrne, B.M. (1991). Burnout: Investigating the impact of background variables for elementary, intermediate, secondary, and university educators. Teaching and Teacher Education, 72, 197-209.

Byrne, B.M. (1999). The nomological network of teacher burnout: A literature review and empirically validated model. In R. Vandenberghe \& A. M. Huberman (Eds.), Understanding and preventing teacher burnout. Cambridge: Cambridge University Press, pp. 15-37.

Centraal Bureau voor de Statistiek. (1999). De leefsituatie van de Nederlandse bevolking 1997. [The social situation of the Dutch population 1997]. Voorburg/Heerlen: Centraal Bureau voor de Statistiek.

Cherniss, C. (1993). Role of professional self-efficacy in the etiology and amelioration of burnout. In W.B. Schaufeli, C. Maslach, \& T. Marek (Eds.), Professional burnout: Recent developments in theory and research. Washington, DC: Taylor \& Francis, pp. 135-150.

Cooley, E. \& Yovanoff, P. (1996). Supporting professionals-at-risk: Evaluating interventions to reduce burnout and to improve retention of special educators. Exceptional Children, 62(4), 336-355.

Den Boer, P.C.A.M., Rombouts, R.P., Appelo, M.T., \& Wolter, H. (1999). De ontwikkeling van de 'Test voor Cognitieve Stijlen (TCS) [The development of the test for Cognitive Styles (TCS)]. Gedragstherapie, 32(2), 105-118.

Ellis, A. (1996). The humanism of rational emotive behavior therapy. Journal of Humanistic Education \& Development, 35(2), 69-89.

Epstein, S. (1982). Conflict and stress. In L. Goldberger \& S. Breznitz (Eds.), Handbook of stress. Theoretical and Clinical Aspects. New York: The Free Press, pp. 49-68.

Epstein, S. (1992). Constructive thinking and mental and physical well-being. In L. Montada, S.H. Filipp, \& M.J. Lerner (Eds.), Life crises \& experiences of loss in adulthood. Hillsdale, NJ: Erlbaum, pp. 385-409. 
Epstein, S. (1998). Constructive thinking: The key to emotional intelligence. London: Praeger Publishers.

Epstein, S. \& Meier, P. (1989). Constructive thinking: A broad coping variable with specific components. Journal of Personality and Social Psychology, 57(2), 332-350.

Evers, W.J.G. (2002). Burnout among teachers. Theoretical setting, top-down innovation, and social relations. Amsterdam: Dissertation University of Amsterdam.

Evers, W.J.G., Brouwers, A., \& Tomic, W. (2002). Burnout and self-efficacy: A study on teachers' beliefs when implementing an innovative educational system in the Netherlands. British Journal of Educational Psychology, 72, 227-245.

Freudenberger, H.J. (1974). Staff burnout. Journal of Social Issues, 30(1), 159-165.

Friedman, I.A. \& Farber, B.A. (1992). Professional self-concept as a predictor of teacher burnout. Journal of Educational Research, 86(1), 28-35.

Glass, D.C. \& McKnight, J.D. (1996). Perceived control, depressive symptomatology, and professional burnout: A review of the evidence. Psychology and Health, 11, 23-48.

Goleman, D. (1996). Emotional intelligence. Why it can matter more than IQ. New York, NY: Bantam Books.

Greenglass, E.R. (2001). Proactive Coping, Work Stress and Burnout. Stress News, 13(2).

Huberman, A.M. \& Vandenberghe, R. (1999). Introduction. In A.M. Huberman \& R. Vandenberghe (Eds.), Understanding and preventing teacher burnout: A sourcebook of international research and practice. Cambridge: Cambridge University Press, pp. 1-11.

Maslach, C. (1982). Understanding burnout: Definitional issues in analyzing a complex phenomenon. In W.S. Paine (Ed.), Job stress and burnout. Beverly Hills, CA: Sage, pp. 29-40.

Maslach, C. \& Jackson, S.E. (1981). The measurement of experienced burnout. Journal of Occupational Behavior, 2, 99-113.

Maslach, C. \& Jackson, S.E. (1986). Maslach burnout inventory manual. Palo Alto, CA: Consulting Psychologists Press.

Nias, J. (1999). Teacher's moral purpose: Stress, vulnerability and strength. In R. Vandenberghe \& A. M. Huberman (Eds.), Understanding and preventing teacher burnout. Cambridge: Cambridge University Press, pp. 15-37.

Nunnally, N. C. \& Bernstein, I. H. (1994). Psychometric theory. (3rd ed.). New York, NY: McGraw-Hill.

Rudow, B. (1999). Stress and Burnout in the teaching profession: European studies, issues, and research perspectives. In R. Vandenberghe \& A.M. Huberman (Eds.), Understanding and preventing teacher burnout. Cambridge: Cambridge University Press, pp. 38-58.

Schaufeli, W.B., Daamen, J., \& Van Mierlo, H. (1994). Burnout among Dutch teachers: An MBI-validity study. Educational and Psychological Measurement, 54(3), 803-812.

Schaufeli, W.B. \& Van Horn, J.E. (1995). Maslach Burnout Inventory voor leraren (MBI-NL-Le). Voorlopige handleiding. [Maslach Burnout Inventory for teachers. Preliminary guide]. University of Utrecht: PALO.

Schmitz, G.S. (2001). Kann Selbstwirksamkeitserwartung Lehrer vor Burnout schützen? [Can self-efficacy beliefs protect teachers from burnout?]. Psychologie in Erziehung und Unterricht, 48, 49-67.

Tomic, W., Evers, W.J.G., \& Brouwers, A. (2004). Existential fulfillment and teacher burnout. European Psychotherapy, 5(1), 65-74.

\section{Biographical notes}

André Brouwers is currently at the Open University of the Netherlands, Department of Psychology. He has published widely in the field of occupational and organizational psychology. His current work centers on coaching. 
Will Evers is a research associate. For the past six years he has worked with André Brouwers and Welko Tomic. His areas of interest are stress and burnout within professional groups and dissemination of research findings.

Welko Tomic is currently at the Open University of the Netherlands, Department of Psychology. He has published extensively on issues related to teacher behavior, inductive reasoning, clergy and teacher burnout. His current work focuses on existential fulfillment and psychosocial disorders. 